Pengaruh Profitabilitas, Kualitas Audit, Independensi Auditor, Ukuran Perusahaan, dan Leverage Terhadap Manajemen Laba

(Studi Empiris Pada Perusahaan Manufaktur Yang Terdaftar Di Bursa Efek Indonesia

Tahun 2013-2015)

\title{
PENGARUH PROFITABILITAS, KUALITAS AUDIT, INDEPENDENSI \\ AUDITOR, UKURAN PERUSAHAAN, DAN LEVERAGE TERHADAP MANAJEMEN LABA
}

(Studi Empiris pada Perusahaan Manufaktur yang Terdaftar di Bursa Efek Indonesia tahun 2013-2015)

\author{
Ayu Winda Pratiwi \\ Universitas Multimedia Nusantara \\ ayu.winda@student.umn.ac.id \\ Patricia Diana \\ Universitas Multimedia Nusantara \\ patricia@umn.ac.id
}

\begin{abstract}
The objective of this research is to obtain empirical evidence about the effect of profitability, audit quality, auditor independency, firm size, and leverage either individually or simultaneously toward earnings management. Dependent variable of this research was earnings management measured by discretionary accruals with modified jones model. Earnings management is an action taken by management to determine current reported earnings based on judgment that may reduce the credibility of the financial statements, so the information presented can mislead decision-makers. Independent variables were profitability, audit quality, auditor independency, firm size, and leverage.

The object in this research was manufacturing companies listed in Indonesia Stock Exchange (IDX) for period 2013 until 2015. The samples in this research were 103 companies listed on IDX in 2013 - 2015 were selected by using purposive sampling method. Secondary data used in this research was analyzed by using multiple regression method.

The results of this research were: (1) Profitability had significant effects on earnings management, (2) Audit quality had no significant effects on earnings management, (3) Auditor independency had no significant effects on earnings management, (4) Firm size had no significant effects on earnings management, and (5) Leverage had no significant effects on earnings management.
\end{abstract}

Keywords: Earnings management, profitability, audit quality, auditor independency, firm size, and leverage

\section{PENDAHULUAN}

Pertumbuhan ekonomi Indonesia tercermin dari pesatnya pertumbuhan perusahaan yang dapat dilihat dari peningkatan harga saham perusahaan, serta peningkatan jumlah perusahaan yang terdaftar di
Bursa Efek Indonesia atau perusahaan go public. Perusahaan go public adalah perusahaan yang sebagian sahamnya dimiliki oleh masyarakat, baik melalui transaksi di pasar primer, yakni pada saat Initial Public Offering (IPO), maupun 
melalui transaksi di pasar sekunder yaitu transaksi jual beli saham di bursa. Adanya kepentingan pihak internal, seperti manajemen, dan pihak eksternal di perusahaan, seperti pemegang saham dan kreditur, membuat penyajian laporan keuangan sangat dibutuhkan untuk memberikan berbagai informasi terkait kondisi perusahaan.

Pernyataan Standar Akuntansi Keuangan (PSAK) 1 revisi 2013 menyatakan laporan keuangan adalah suatu penyajian terstruktur dari posisi keuangan dan kinerja keuangan suatu entitas. Laporan keuangan dapat digunakan untuk mengetahui kondisi perusahaan yang sebenarnya, serta dapat dijadikan dasar dalam pengambilan keputusan. Laporan keuangan perusahaan go public wajib dipublikasikan setelah terlebih dahulu diaudit oleh auditor eksternal.

Informasi laba dalam laporan keuangan sering digunakan sebagai indikator pengukuran kinerja atau pertanggungjawaban manajemen dalam menjalankan perusahaan. Laba yang dilaporkan merupakan laba akrual perusahaan yang memiliki kemungkinan untuk dimanipulasi. Menurut Scott (2012), manajemen yang melakukan pengelolaan laba dapat bertujuan efisien dan oportunis. Pengelolaan laba yang bertujuan efisien diartikan bahwa manajemen diberikan fleksibilitas untuk mengelola laba dengan tujuan melindungi perusahaan dalam mengantisipasi kejadian tak terduga yang dapat mempengaruhi nilai pasar perusahaan. Sedangkan, pengelolaan laba yang bertujuan oportunis dilakukan manajemen untuk kepentingan pihak tertentu yang dampaknya dapat merugikan perusahaan. Pengelolaan laba ini disebut juga dengan manajemen laba. Penelitian ini membahas tentang manajemen laba yang terjadi di perusahan manufaktur. Manajemen laba menurut Scott (2012) adalah suatu tindakan manajemen untuk memilih kebijakan akuntansi dari suatu standar tertentu dengan tujuan memaksimalkan kesejahteraan pihak manajemen dan/atau nilai pasar perusahaan. Manajemen laba dapat dilakukan dengan tiga teknik, yaitu memanfaatkan peluang untuk membuat estimasi akuntansi, mengubah metode akuntansi, serta 
(Studi Empiris Pada Perusahaan Manufaktur Yang Terdaftar Di Bursa Efek Indonesia

Tahun 2013-2015)

menggeser periode biaya atau pendapatan (Kusumawardhani, 2012).

Dalam penelitian ini manajemen laba diukur menggunakan discretionary accruals. Discretionary accruals adalah komponen akrual yang berada di dalam kebijakan manajemen, dimana manajemen melakukan intervensi dalam proses pelaporan (Purwanti, 2012). Contoh dari discretionary accruals adalah pembentukan cadangan kerugian piutang pada periode berjalan yang relatif lebih besar atau lebih kecil pada periode sebelumnya, sehingga akan lebih mencerminkan laba yang ingin dicapai perusahaan pada periode berjalan (Erawan dan Ulupui, 2013).

Terdapat faktor-faktor yang diperkirakan akan mempengaruhi manajemen laba, di antaranya adalah profitabilitas, kualitas audit, independensi auditor, ukuran perusahaan, dan leverage. Faktor pertama yang diperkirakan akan mempengaruhi manajemen laba adalah profitabilitas yang diproksikan dengan Return on Assets (ROA). Profitabilitas merupakan kemampuan perusahaan dalam memperoleh keuntungan atau laba (Amertha, 2013). Semakin tinggi profitabilitas perusahaan menunjukkan bahwa laba yang dihasilkan perusahan juga tinggi. Laba yang tinggi akan mengakibatkan beban pajak yang harus dibayarkan juga semakin tinggi. Hal ini dapat mendorong manajemen untuk melakukan manajemen laba dengan cara mengecilkan laba yang dilaporkan daripada laba yang sebenarnya, sehingga jumlah beban pajak yang dibayarkan akan mengecil.

Faktor kedua yang diperkirakan akan mempengaruhi manajemen laba adalah kualitas audit yang diproksikan dengan ukuran Kantor Akuntan Publik (KAP) yang terdiri dari KAP Big Four dan KAP Nonbig Four. KAP Big Four diasumsikan melakukan audit yang lebih berkualitas dikarenakan auditor yang bekerja di KAP Big Four pada umumnya memiliki lebih banyak pengalaman dalam mengaudit klien dari berbagai macam jenis industri. Selain itu, auditor di KAP Big Four telah menjalani training lebih banyak dan memiliki pemahaman mendalam terhadap suatu industri (spesialisasi), 
sehingga diasumsikan auditor lebih cakap dalam melakukan audit dan menemukan penyimpangan yang terdapat di laporan keuangan klien. Klien cenderung menjadi lebih berhati-hati dan transparan dalam menyusun laporan keuangannya sehingga kecil kemungkinan perusahaan melakukan manajemen laba.

Faktor ketiga yang diperkirakan akan mempengaruhi manajemen laba adalah independensi auditor yang diproksikan dengan audit tenure. Independensi seorang akuntan publik merupakan suatu hal yang mutlak, sesuai dengan peryataan Standar Umum dalam Pernyataan Standar Auditing (PSA) No.4 "Dalam semua hal yang berhubungan dengan perikatan, independensi dalam sikap mental harus dipertahankan oleh seorang auditor." (IAPI, 2011). Semakin lama auditor melaksanakan audit pada suatu perusahaan, maka terdapat kecenderungan atas penurunan independensi auditor. Hal ini dapat menyebabkan timbulnya indikasi manajemen laba di dalam perusahaan yang diaudit, karena semakin lama hubungan yang terjalin antara auditor dengan klien dapat memunculkan potensi auditor memiliki hubungan yang dekat dengan klien sehingga dapat mempersulit auditor dalam pengambilan keputusan audit.

Faktor keempat yang diperkirakan akan mempengaruhi manajemen laba adalah ukuran perusahaan yang diproksikan dengan logaritma total aset. Keputusan ketua BAPEPAM No. Kep 11/PM/1997 menyebutkan perusahaan kecil dan menengah adalah badan hukum yang memiliki jumlah kekayaan (total aset) tidak lebih dari seratus milyar rupiah, sedangkan perusahaan besar adalah badan hukum yang memiliki total aktiva di atas seratus milyar rupiah. Perusahaan berukuran besar cenderung lebih diperhatikan oleh publik dikarenakan perusahaan memiliki peran sebagai pemegang kepentingan yang lebih luas. Hal ini akan mendorong perusahaan untuk menyajikan laporan keuangannya secara lebih transparan, terstruktur, lengkap, dan akurat, sehingga kecil kemungkinan terjadinya manajemen laba.

Faktor lainnya yang diperkirakan akan mempengaruhi manajemen laba adalah leverage yang diproksikan 
(Studi Empiris Pada Perusahaan Manufaktur Yang Terdaftar Di Bursa Efek Indonesia

Tahun 2013-2015)

dengan debt to assets ratio. Semakin tinggi leverage yang dimiliki perusahaan, maka kemungkinan manajemen melakukan manajemen laba semakin tinggi. Hal ini dikarenakan nilai leverage yang tinggi menunjukkan bahwa perusahaan memiliki proporsi utang yang besar untuk pembiayaan asetnya. Akibatnya perusahaan mengalami kesulitan dalam melunasi kewajibannya, sehingga untuk meningkatkan kepercayaan kreditur, perusahaanmelakukan manajemen laba agar laporan yang dihasilkan memberikan sinyal bahwa perusahaan mampu melunasi utangnya.

\section{TELAAH LITERATUR}

\subsection{Teori Keagenan}

Menurut Godfrey et al. (2014) teori keagenan atau agency theory muncul ketika terdapat kontrak antara pemilik (principal) dan manajemen (agent) untuk melakukan suatu pekerjaan berdasarkan kepentingan pemilik. Adanya pemisahan kepemilikan dan pengelolaan perusahaan dapat mendorong setiap pihak berusaha memaksimalkan kesejahteraan masing-masing. Situasi ini akan menimbulkan konflik kepentingan antara pemilik dan manajemen karena tidak bertemunya utilitas yang maksimal antara mereka (Kusumaningtyas, 2012). Konflik kepentingan antara pemilik dan manajemen ini disebut sebagai masalah keagenan.

Dalam hal pertimbangan oportunis, manajemen dapat melakukan penyembunyian, penundaan pengungkapan atau pengubahan informasi yang akan diberikan kepada pihak eksternal. Hal ini menyebabkan pihak eksternal memperoleh informasi yang tidak lengkap atau bahkan tidak relevan dengan keadaan perusahaan yang sebenarnya, dan dapat mengakibatkan pengambilan keputusan yang tidak tepat. Keadaan ini dikenal sebagai asimetri informasi. Asimetri informasi adalah situasi yang terbentuk ketika pemilik tidak memiliki informasi yang cukup mengenai kinerja keuangan manajemen, sehingga pemilik tidak mengetahui secara pasti bagaimana usaha manajemen memberikan kontribusi pada hasil aktual perusahaan (Wiryadi \& Sebrina, 2013). 
Manajemen sebagai pengelola perusahaan yang memiliki informasi internal yang dapat digunakan untuk memprediksi prospek di masa depan berkewajiban untuk menyampaikan hal ini kepada pihak yang berkepentingan, seperti pemegang saham dan kreditur. Namun, akibat adanya perbedaan kepentingan, asimetri informasi, serta kecenderungan dari pihak eksternal untuk memperhatikan informasi laba sebagai parameter kinerja perusahaan, maka penyajian laporan keuangan dapat dimanipulasi demi kepentingan pihak tertentu yang dapat merugikan perusahaan. Tindakan manipulasi laporan keuangan dikenal dengan manajemen laba.

\subsection{Manajemen Laba}

Manajemen laba terjadi ketika manajemen menggunakan penilaian dalam pelaporan keuangan dan penyusunan transaksi untuk mengubah laporan, dengan tujuan untuk memanipulasi besaran laba kepada beberapa stakeholders tentang kinerja keuangan perusahaan atau untuk mempengaruhi hasil perjanjian (kontrak) yang bergantung pada angka-angka akuntansi yang dilaporkan (Healy dan Wahlen, 1999 dalam Kusumaningtyas, 2012). Manajemen laba merupakan suatu tindakan yang dilakukan oleh manajemen untuk menentukan laba perusahaan berdasarkan penilaiannya yang dapat mengurangi kredibilitas laporan keuangan sehingga informasi yang disajikan dapat menyesatkan pembuat keputusan.

Manajemen laba dapat dilakukan dengan merekayasa laba menjadi lebih besar, lebih kecil atau dengan meratakan laba selama beberapa periode. Menurut Scott (2012:425) pola manajemen laba terbagi menjadi empat macam:

\section{Taking a bath}

Taking a bath adalah pola manajemen laba yang dilakukan dengan cara menjadikan laba perusahaan pada periode berjalan menjadi sangat ekstrim rendah (bahkan rugi) dibandingkan dengan laba pada periode sebelumnya atau sesudahnya. Dalam pola ini, manajemen mengakui biaya-biaya periode yang akan datang dan kerugian pada periode berjalan. Periode yang dipilih biasanya ketika 
Pengaruh Profitabilitas, Kualitas Audit, Independensi Auditor, Ukuran Perusahaan, dan Leverage Terhadap Manajemen Laba (Studi Empiris Pada Perusahaan Manufaktur Yang Terdaftar Di Bursa Efek Indonesia

Tahun 2013-2015)

perusahaan memiliki kinerja

kurang baik (seringnya ketika

resesi, di mana perusahaan lain juga melaporkan kerugian).

\section{Income minimization}

Income minimization adalah pola manajemen laba yang dilakukan dengan cara menjadikan laba di laporan keuangan periode berjalan lebih rendah daripada laba sebenarnya. Income minimization biasanya dilakukan pada saat profitabilitas perusahaan sangat tinggi dengan maksud agar tidak mendapat perhatian secara politis.

\section{Income maximization}

Income maximization adalah pola manajemen laba yang dilakukan dengan cara menjadikan laba di laporan keuangan periode berjalan lebih tinggi daripada laba sebenarnya. Pola ini dilakukan dengan cara mempercepat pencatatan pendapatan, menunda biaya atau memindahkan biaya untuk periode lain.

\section{Income smoothing}

Income smoothing adalah pola manajemen laba yang dilakukan dengan cara membuat laba akuntansi relatif konsisten (rata atau smooth) dari periode ke periode. Dalam hal ini, manajemen dengan sengaja menurunkan atau meningkatkan laba untuk mengurangi fluktuasi dalam pelaporan laba, sehingga perusahaan terlihat stabil atau tidak berisiko tinggi, serta bonus yang didapatkan manajemen relatif konstan.

Motivasi manajemen laba menurut Subramanyam (2014) di antaranya adalah:

1. Insentif Perjanjian

Perjanjian kompensasi biasanya berupa bonus yang didasarkan pada laba. Dalam perjanjian bonus ditentukan batas atas dan batas bawah. Manajemen tidak akan mendapatkan bonus apabila laba yang dicapai melebihi batas bawah maupun batas atas. Hal ini mendorong manajemen untuk meningkatkan atau mengurangi laba berdasarkan batas atas dan batas bawah tersebut agar manajemen cenderung akan selalu memperoleh bonus dari suatu periode ke periode berikutnya.

2. Dampak Harga Saham

Manajemen dapat meningkatkan laba untuk menaikkan sementara harga saham perusahaan selama 
suatu kejadian tertentu seperti merger, penawaran surat berharga, penjualan saham, atau opsi. Manajemen juga dapat melakukan perataan laba untuk menurunkan persepsi pasar akan risiko.

\section{Insentif lain}

Laba seringkali diturunkan untuk menghindari biaya politik dan memperoleh keuntungan dari pemerintah, misalnya subsidi atau menghindari biaya pajak yang terlalu tinggi.

Manajemen laba memiliki beberapa teknik yang diungkapkan oleh Subramanyam (2014), yaitu:

\section{Income Shifting}

Income shifting atau pemindahan laba merupakan tindakan manajemen laba dengan memindahkan laba dari satu periode ke periode lainnya. Pemindahan laba dapat dilakukan dengan mempercepat atau menunda pengakuan pendapatan dan beban. Income shifting sering dilakukan dengan tujuan untuk perataan laba.

2. Klasifikasi

Laba dapat ditentukan dengan mengklasifikasi beban dan pendapatan secara khusus pada bagian tertentu dalam laporan laba rugi.

Untuk mendeteksi ada atau tidaknya manajemen laba, maka pengukuran atas akrual sangat penting untuk dilakukan. Sulistyanto (2008:161) menyatakan manajemen laba dilakukan dengan memanipulasi komponen-komponen akrual dalam laporan keuangan, komponen akrual merupakan komponen yang tidak memerlukan bukti kas secara fisik sehingga upaya memanipulasi besar kecilnya komponen akrual tidak harus disertai dengan kas yang diterima atau dikeluarkan perusahaan. Healy (1985) dalam Christiani dan Nugrahanti (2014) menyatakan konsep model akrual memiliki dua komponen, yaitu komponen non-discretionary dan discretionary. Discretionary accrual merupakan komponen akrual yang dapat diatur dan direkayasa sesuai kebijakan (discretion) manajerial, sehingga laba yang dilaporkan dalam laporan keuangan tidak mencerminkan nilai atau kondisi perusahaan yang sebenarnya. Hal ini disebabkan karena manajemen memiliki kemampuan untuk 
(Studi Empiris Pada Perusahaan Manufaktur Yang Terdaftar Di Bursa Efek Indonesia

Tahun 2013-2015)

mengontrol komponen ini dalam jangka pendek. Komponen discretionary accrual di antaranya terdiri dari penilaian piutang, pengakuan biaya garansi (future warranty expense) dan kapitalisasi aset (capitalization assets). Sedangkan komponen nondiscretionary accrual adalah pengakuan akrual laba yang wajar, yang tunduk pada suatu standar atau prinsip akuntansi yang berlaku umum (Kusumaningtyas, 2012). Non discretionary accrual merupakan akrual yang wajar, dan apabila dilanggar akan mempengaruhi kualitas laporan keuangan (tidak wajar). Manajemen laba diukur menggunakan nilai discretionary accruals. Jika nilai discretionary accruals perusahaan negatif berarti manajemen laba yang dilakukan oleh perusahaan yaitu dengan cara menurunkan laba, sebaliknya jika nilai discretionary accruals perusahaan positif berarti manajemen laba yang dilakukan oleh perusahaan yaitu dengan cara menaikkan laba (Wiryadi dan Sebrina, 2013).

\subsection{Profitabilitas}

Profitabilitas merupakan tingkat kemampuan perusahaan dalam mengelola asetnya untuk memperoleh laba (Amertha, 2013). Laba yang disajikan pada laporan keuangan digunakan sebagai indikator kinerja pihak manajemen dalam mengelola kekayaan perusahaan. Profitabilitas dapat dilihat dari Return on Assets (ROA) perusahaan. ROA menunjukkan seberapa besar kontribusi aset dalam menghasilkan laba perusahaan. Nilai ROA positif menunjukkan bahwa manajemen dianggap mampu mengelola aset perusahaan dengan baik untuk menghasilkan laba. Sedangkan nilai ROA negatif menunjukkan bahwa manajemen dianggap gagal dalam mengelola aset perusahaan untuk menghasilkan laba. Semakin tinggi laba yang diperoleh perusahaan, semakin besar juga kewajiban perpajakan yang harus diselesaikan perusahaan. Sebaliknya, semakin rendah laba perusahaan, maka semakin kecil juga beban pajak yang harus dibayarkan. Perusahaan cenderung berusaha untuk meminimalisasi beban, termasuk beban pajak yang harus dibayar. Hal 
ini dapat memotivasi manajemen untuk melakukan tindakan manajemen laba dengan cara mengecilkan jumlah laba yang dilaporkan.

Pernyataan variabel profitabilitas memiliki pengaruh terhadap manajemen laba didukung oleh penelitian yang dilakukan Atarwaman (2011), Amertha (2013), serta Prabayanti dan Yasa (2011). Perusahaan yang memiliki laba besar cenderung melakukan manajemen laba daripada perusahaan yang memiliki laba kecil. Namun, menurut Noviana dan Yuyetta (2011) profitabilitas tidak berpengaruh terhadap manajemen laba. Berdasarkan uraian di atas, maka hipotesis dalam penelitian ini adalah sebagai berikut:

$\mathrm{Ha}_{1}$ : Profitabilitas yang diproksikan dengan Return on Assets (ROA) berpengaruh terhadap manajemen laba.

\subsection{Kualitas Audit}

Menurut Keputusan Ketua

BAPEPAM No Kep-346/BL/2011, laporan keuangan wajib disertai dengan laporan akuntan dalam rangka audit atas laporan keuangan.
Kualitas auditor akan berpengaruh terhadap hasil audit yang dilakukan oleh auditornya (Pambudi dan Sumantri, 2014). Purwanti (2012) menyatakan bahwa auditor berkualitas tinggi lebih memilih untuk melaporkan kesalahan dan penyimpangan dan tidak mau menerima praktik akuntansi yang menimbulkan pertanyaan, sehingga auditor yang berkualitas akan memiliki kemungkinan lebih besar untuk mendeteksi manajemen laba. Penelitian ini akan membahas kualitas audit yang diproksikan dengan ukuran Kantor Akuntan Publik (KAP).

KAP berukuran besar diasumsikan melakukan audit yang lebih berkualitas dibandingkan dengan KAP berukuran kecil. Hal ini dikarenakan auditor yang bekerja di KAP yang berukuran lebih besar pada umumnya memiliki lebih banyak pengalaman dalam mengaudit klien dari berbagai macam jenis industri. Selain itu, auditor di KAP berukuran besar telah menjalani training lebih banyak dan memiliki pemahaman mendalam terhadap suatu industri (spesialisasi), sehingga diasumsikan auditor lebih 
(Studi Empiris Pada Perusahaan Manufaktur Yang Terdaftar Di Bursa Efek Indonesia

Tahun 2013-2015)

cakap dalam melakukan audit dan menemukan penyimpangan yang terdapat di laporan keuangan klien. Klien cenderung menjadi lebih berhati-hati dan transparan dalam menyusun laporan keuangannya sehingga kecil kemungkinan perusahaan melakukan manajemen laba. Menurut penelitian yang dilakukan oleh Gerayli et al. (2011) kualitas audit berpengaruh terhadap manajemen laba. Tetapi, penelitian Pambudi dan Sumantri (2014) mengatakan variabel kualitas audit tidak berpengaruh terhadap manajemen laba. Berdasarkan uraian di atas, maka hipotesis dalam penelitian ini adalah sebagai berikut: $\mathrm{Ha}_{2}$ : Kualitas audit yang diproksikan dengan ukuran KAP berpengaruh terhadap manajemen laba.

\subsection{Independensi Auditor}

Independensi merupakan kejujuran pada diri auditor dalam mempertimbangkan fakta dan adanya pertimbangan yang objektif untuk tidak memihak dalam diri auditor untuk merumuskan dan menyatakan pendapatnya (Tjun Tjun dkk, 2012).
Dalam penelitian ini, independensi auditor diproksikan dengan audit tenure. Audit tenure adalah lamanya penugasan KAP tersebut di perusahaan yang sama. Semakin lama auditor melaksanakan audit di suatu perusahaan, maka independensi auditor dianggap menurun. Hal ini dikarenakan semakin lama hubungan kerja auditor dengan klien akan memunculkan satu fenomena saling membutuhkan, sehingga pola hubungan auditor dengan klien akan dapat berubah menjadi partner kerja dan hal tersebut akan berbahaya bagi pengambilan keputusan audit dari auditor. Menurut Peraturan Pemerintah No. 20 Tahun 2015, pemberian jasa audit umum atas laporan keuangan klien oleh seorang Akuntan Publik dibatasi paling lama untuk 5 (lima) tahun buku berturutturut.

Auditor yang memiliki independensi tinggi lebih mudah mengungkapkan kecurangan yang terjadi di perusahaan kliennya. Sedangkan auditor yang independensinya diragukan cenderung menutupi hasil temuannya di perusahaan tersebut. Independensi auditor yang tidak baik 
akan memunculkan indikasi manajemen laba di perusahaan yang diauditnya. Gerayli et al. (2011) menyatakan bahwa independensi auditor berpengaruh terhadap manajemen laba, sedangkan Amijaya dan Prastiwi (2013) menyatakan independensi auditor tidak berpengaruh terhadap manajemen laba. Berdasarkan uraian di atas, maka hipotesis dalam penelitian ini adalah sebagai berikut:

$\mathrm{Ha}_{3}$ : Independensi auditor yang diproksikan dengan audit tenure berpengaruh terhadap manajemen laba.

\subsection{Ukuran Perusahaan}

Ukuran perusahaan adalah suatu skala untuk mengklasifikasikan besar kecilnya perusahaan dengan dasar pengukuran antara lain total aset, penjualan dan nilai pasar saham (Kusumawardhani, 2013). Keputusan ketua BAPEPAM No. Kep 11/PM/1997 menyebutkan perusahaan kecil dan menengah adalah badan hukum yang memiliki jumlah kekayaan (total aset) tidak lebih dari seratus milyar rupiah, sedangkan perusahaan besar adalah badan hukum yang memiliki total aktiva di atas seratus milyar rupiah. Semakin besar ukuran perusahaan maka informasi yang digunakan dalam pengambilan keputusan juga semakin banyak (Kusumawardhani, 2013). Keputusan yang diambil tersebut cenderung mendapatkan perhatian lebih dari analis dan para investor. Seluruh informasi yang disajikan perusahaan besar disajikan secara lebih terstruktur dan lengkap, karena pentingnya transparansi dalam hal tersebut. Manajemen akan lebih berhati-hati dalam melakukan pelaporan keuangan dan perusahaan melaporkan kondisinya dengan lebih akurat, sehingga indikasi terjadinya manajemen laba lebih rendah dibandingkan dengan perusahaan kecil. Menurut Pambudi dan Sumantri (2014) serta Limanto dan Fanani (2014) ukuran perusahaan berpengaruh terhadap manajemen laba. Sedangkan Purwanti (2012) menyatakan ukuran perusahaan tidak berpengaruh terhadap manajemen laba. Berdasarkan uraian di atas, maka hipotesis dalam penelitian ini adalah sebagai berikut:

$\mathrm{Ha}_{4}$ : Ukuran perusahaan yang diproksikan dengan log total 
Pengaruh Profitabilitas, Kualitas Audit, Independensi Auditor, Ukuran Perusahaan, dan Leverage Terhadap Manajemen Laba (Studi Empiris Pada Perusahaan Manufaktur Yang Terdaftar Di Bursa Efek Indonesia

Tahun 2013-2015) aset berpengaruh terhadap manajemen laba.

\subsection{Leverage}

Leverage merupakan proporsi penggunaan utang untuk membiayai investasi atau aset perusahaan (Noviana dan Yuyetta, 2011). Pambudi dan Sumantri (2014) menyatakan bahwa semakin tinggi nilai leverage maka risiko yang akan dihadapi investor akan semakin tinggi dan para investor akan meminta keuntungan yang semakin besar. Perusahaan juga akan bergantung pada kreditur karena besarnya pembiayaan yang diperoleh dari kreditur.

Semakin tinggi leverage yang dimiliki perusahaan, maka kemungkinan manajemen melakukan manajemen laba semakin tinggi. Hal ini dikarenakan nilai leverage yang tinggi menunjukkan bahwa perusahaan memiliki proporsi utang yang besar untuk pembiayaan asetnya. Akibatnya perusahaan mengalami kesulitan dalam melunasi kewajibannya, sehingga untuk meningkatkan kepercayaan kreditur, perusahaanmelakukan manajemen laba agar laporan yang dihasilkan memberikan sinyal bahwa perusahaan mampu melunasi utangnya.

Menurut Agustia (2013) serta Limanto dan Fanani (2014) leverage berpengaruh terhadap manajemen laba, sedangkan Pambudi dan Sumantri (2014) menyatakan leverage tidak berpengaruh terhadap manajemen laba. Berdasarkan uraian di atas, maka hipotesis dalam penelitian ini adalah sebagai berikut: $\mathrm{Ha}_{5}$ : Leverage yang diproksikan dengan debt to asset ratio berpengaruh terhadap manajemen laba. 


\subsection{Model Penelitian}

Variabel Independen

Variabel Dependen

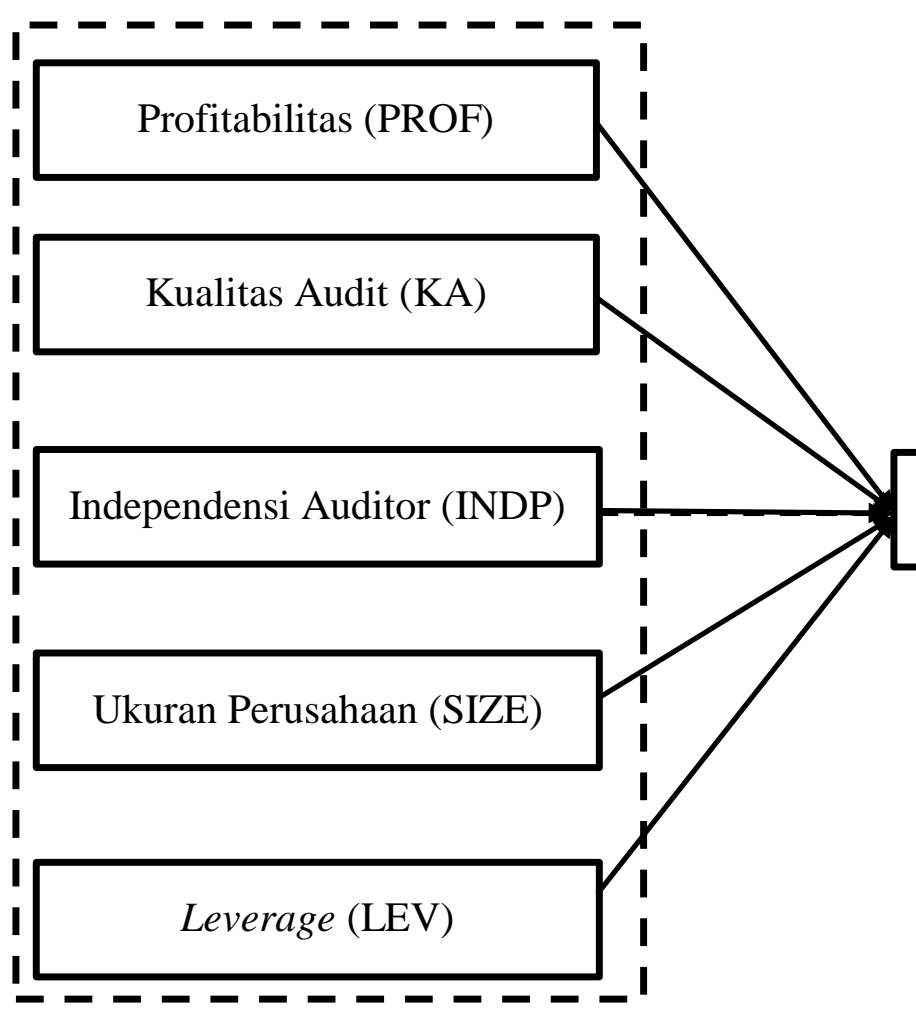

Gambar 1. Kerangka Penelitian

3. METODOLOGI PENELITIAN

\subsection{Gambaran Umum Objek Penelitian}

Objek penelitian yang diteliti adalah perusahaan manufaktur yang terdaftar di Bursa Efek Indonesia tahun $2013-2015$.

\subsection{Metode Penelitian}

Metode penelitian yang digunakan dalam penelitian ini adalah causal study, yaitu studi dimana peneliti ingin menggambarkan penyebab dari satu atau lebih permasalahan (Sekaran dan Bougie, 2013).

\subsection{Variabel Penelitian}

\subsubsection{Variabel Dependen}

Variabel dependen adalah variabel yang dipengaruhi pada suatu penelitian untuk menjelaskan variabilitasnya (Sekaran dan Bougie, 2013). Variabel dependen dalam penelitian ini adalah manajemen laba. Manajemen laba diproksikan dengan menggunakan discretionary accruals dan dihitung menggunakan 
Pengaruh Profitabilitas, Kualitas Audit, Independensi Auditor, Ukuran Perusahaan, dan Leverage Terhadap Manajemen Laba

(Studi Empiris Pada Perusahaan Manufaktur Yang Terdaftar Di Bursa Efek Indonesia

Tahun 2013-2015)

Model Jones Dimodifikasi. Sumantri (2014) dirumuskan sebagai Pengukuran discretionary accruals berikut:

menurut penelitian Pambudi dan a. Menghitung total accrual dengan persamaan:

$\mathrm{TAC}=\mathrm{NI}_{\mathrm{t}}-\mathrm{CFO}_{\mathrm{it}}$

Keterangan:

TAC : Total Accrual

$\mathrm{NI}_{\mathrm{t}} \quad$ : Laba bersih perusahaan $\mathrm{i}$ pada periode ke-t

$\mathrm{CFO}_{\text {it }}$ : Aliran kas dari aktivitas operasi perusahaan i pada periode ke- $t$ b. Menghitung nilai accruals dengan persamaan regresi atau Ordinary Least Square (OLS) dengan persamaan:

$$
\frac{\mathrm{TAC}_{\mathrm{t}}}{\mathrm{A}_{\mathrm{it}-1}}=\alpha_{1}\left(\frac{1}{\mathrm{~A}_{\mathrm{it}-1}}\right)+\alpha_{2}\left(\frac{\Delta \mathrm{ReVt}}{\mathrm{A}_{\mathrm{it}-1}}\right)+\alpha_{3}\left(\frac{\mathrm{PPEt}}{\mathrm{A}_{\mathrm{it}-1}}\right)+\varepsilon
$$

Keterangan:

$\mathrm{A}_{\mathrm{it}-1} \quad$ : Total aset perusahaan $\mathrm{i}$

pada periode ke $\mathrm{t}-1$

$\Delta \operatorname{Rev}_{\mathrm{t}}:$ Perubahan pendapatan perusahaan i pada periode ke-t

$\mathrm{PPE}_{\mathrm{t}}$ : Gross property, plant, and equipment perusahaan i pada periode ke-t c. Dengan menggunakan koefisien regresi di atas, nilai nondiscretionary accruals (NDA) dapat dihitung dengan persamaan regresi linear sederhana:

$$
\mathrm{NDA}_{i t}=\alpha_{1}\left(\frac{1}{\mathrm{~A}_{\mathrm{it}-1}}\right)+\alpha_{2}\left(\frac{\Delta \mathrm{ReV}_{\mathrm{t}}-\Delta \mathrm{Rec}_{\mathrm{t}}}{\mathrm{A}_{\mathrm{it}-1}}\right)+\alpha_{3}\left(\frac{\mathrm{PPE}_{\mathrm{t}}}{\mathrm{A}_{\mathrm{it}-1}}\right)
$$


Keterangan:

$\mathrm{NDA}_{i t}$ : Non Discretionary

Accruals perusahaan i

pada periode ke- $t$

$\Delta \operatorname{Rec}_{\mathrm{t}}:$ Perubahan piutang

perusahaan i pada periode

ke-t $\alpha \quad$ : fitted coefficient yang

diperoleh dari hasil

regresi pada perhitungan

total accruals

d. Menghitung nilai discretionary accruals dengan persamaan:

$$
\mathrm{DAC}_{\mathrm{t}}=\frac{\mathrm{TAC}_{\mathrm{t}}}{\mathrm{A}_{\mathrm{it}-1}}-\mathrm{NDA}_{\mathrm{i}}
$$

Keterangan:

$\mathrm{DAC}_{\mathrm{t}}$ : Discretionary Accruals perusahaan i pada periode ke-t

Nilai discretionary accrual positif menunjukkan perusahaan melakukan manajemen laba dengan cara menaikkan laba, sedangkan nilai discretionary accrual negatif menunjukkan perusahaan melakukan manajemen laba dengan cara menurunkan laba.

\subsubsection{Variabel Independen}

\subsubsection{Profitabilitas}

Profitabilitas dalam penelitian ini diproksikan skala rasio Return on Assets (ROA) dan dirumuskan sebagai berikut (Subramanyam, 2014):

$$
\mathrm{ROA}=\frac{\text { Net Income }}{\text { Average Total Assets }}
$$

\subsubsection{Kualitas Audit}

Kualitas audit dalam penelitian ini diproksikan dengan ukuran KAP yang diukur menggunakan skala nominal variabel dummy. Angka 1 digunakan untuk mewakili perusahaan yang diaudit oleh KAP Big Four dan angka 0 digunakan untuk mewakili perusahaan yang diaudit oleh KAP Non Big Four (Pambudi dan Sumantri, 2014).

\subsubsection{Independensi Auditor}

Independensi auditor dalam penelitian ini diproksikan dengan audit tenure. Nilai audit tenure dihitung dengan menjumlah total lamanya perikatan suatu audit sebelum auditor berpindah 
Pengaruh Profitabilitas, Kualitas Audit, Independensi Auditor, Ukuran Perusahaan, dan Leverage Terhadap Manajemen Laba

(Studi Empiris Pada Perusahaan Manufaktur Yang Terdaftar Di Bursa Efek Indonesia

Tahun 2013-2015)

(Saksakotoma dan Cahyonowati,

\subsubsection{Ukuran Perusahaan} 2012).

Ukuran perusahaan dalam penelitian ini diproksikan dengan logaritma total aset (Pambudi dan Sumantri, 2014).

$\mathrm{SIZE}=\log$ Total Assets

\subsubsection{Leverage}

ratio dan dirumuskan sebagai berikut Leverage dalam penelitian ini (Subramanyam, 2014):

diproksikan dengan debt to assets

$$
\mathrm{LEV}=\frac{\text { Total Utang }}{\text { Total Aset }}
$$

\subsection{Teknik Pengumpulan Data}

Data yang digunakan dalam penelitian ini adalah data sekunder.

Data tersebut merupakan data yang tersaji di dalam laporan keuangan tahunan perusahaan manufaktur periode 2013 - 2015. Data laporan keuangan diperoleh dari situs www.idx.co.id, The Indonesia Capital Market Institute (TICMI), dan situs resmi (website) perusahaan.

\subsection{Teknik Pengambilan Sampel}

Pemilihan sampel penulis menggunakan teknik purposive sampling. Purposive sampling adalah metode pengambilan sampel berdasarkan kriteria-kriteria tertentu yang ditetapkan (Sekaran dan Bougie, 2013). Kriteria yang digunakan dalam penelitian ini sebagai berikut:

1. Perusahaan manufaktur yang terdaftar di BEI dan menerbitkan laporan keuangan audited secara berturut-turut selama periode $2013-2015$.

2. Perusahaan manufaktur yang menerbitkan laporan keuangan yang dinyatakan dalam Rupiah.

3. Perusahaan manufaktur yang menerbitkan laporan keuangan yang berakhir pada tanggal 31 
Desember dan memiliki periode operasional 12 bulan.

\section{HASIL \& ANALISIS}

Manajemen laba dalam penelitian ini

\subsection{Teknik Analisis Data}

Penelitian ini menggunakan SPSS 21 dalam melakukan analisis data. Analisis data yang dilakukan terdiri dari uji statistik deskriptif, uji normalitas, uji asumsi klasik, dan uji hipotesis dengan analisis regresi diukur dengan skala rasio dan diproksikan dengan menggunakan discretionary accruals. Langkah pertama dalam mencari nilai discretionary accruals adalah dengan menghitung total accruals dengan persamaan sebagai berikut:

berganda.

$$
\mathrm{TAC}=\mathrm{NI}_{\mathrm{t}}-\mathrm{CFO}_{\mathrm{it}}
$$

Langkah selanjutnya adalah Ordinary Least Square (OLS) menghitung nilai accruals dengan persamaan sebagai berikut: menggunakan persamaan regresi atau

$$
\frac{\mathrm{TAC}_{\mathrm{t}}}{\mathrm{A}_{\mathrm{it}-1}}=\alpha_{1}\left(\frac{1}{\mathrm{~A}_{\mathrm{it}-1}}\right)+\alpha_{2}\left(\frac{\Delta \mathrm{ReV}_{\mathrm{t}}}{\mathrm{A}_{\mathrm{it}-1}}\right)+\alpha_{3}\left(\frac{\mathrm{PPE}_{\mathrm{t}}}{\mathrm{A}_{\mathrm{it}-1}}\right)+\varepsilon
$$

Dari persamaan regresi tersebut mendapatkan hasil regresi berikut:

Tabel 1. Hasil Regresi Accruals

\begin{tabular}{|c|c|c|c|c|c|c|}
\hline \multirow{2}{*}{\multicolumn{2}{|c|}{ Model }} & \multicolumn{2}{|c|}{ Unstandardized Coefficients } & \multirow{2}{*}{$\begin{array}{c}\begin{array}{c}\text { Standardized } \\
\text { Coefficients }\end{array} \\
\text { Beta }\end{array}$} & \multirow[b]{2}{*}{$\mathrm{t}$} & \multirow[b]{2}{*}{ Sig. } \\
\hline & & $\mathrm{B}$ & Std. Error & & & \\
\hline \multirow[t]{4}{*}{1} & (Constant) & .035 & .013 & & 2.650 & .008 \\
\hline & $\mathrm{X} 1$ & 955403970.5 & 3022914296 & .017 & .316 & .752 \\
\hline & $\mathrm{X} 2$ & .087 & .021 & .219 & 4.065 & .000 \\
\hline & $\mathrm{X} 3$ & -.071 & .015 & -.259 & -4.813 & .000 \\
\hline
\end{tabular}

Coefficients $^{a}$

a. Dependent Variable: TACAt1

Keterangan: 
Pengaruh Profitabilitas, Kualitas Audit, Independensi Auditor, Ukuran Perusahaan, dan Leverage Terhadap Manajemen Laba (Studi Empiris Pada Perusahaan Manufaktur Yang Terdaftar Di Bursa Efek Indonesia

Tahun 2013-2015)

$$
\begin{aligned}
& X 1=\frac{1}{A_{i t-1}} \\
& X 2=\frac{\Delta R e t_{t}}{A_{i t-1}} \\
& X 3=\frac{P P E t}{A_{i t-1}}
\end{aligned}
$$

Dari Tabel 1 diperoleh nilai $\alpha_{1}, \alpha_{2}$, accruals dengan persamaan sebagai dan $\alpha_{3}$ yang digunakan untuk berikut:

menghitung nilai non-discretionary

$$
\mathrm{NDA}_{\mathrm{it}}=955403970,5\left(\frac{1}{\mathrm{~A}_{\mathrm{it}-1}}\right)+0,087\left(\frac{\Delta \mathrm{ReV}_{\mathrm{t}}-\Delta \mathrm{Rec}_{\mathrm{t}}}{\mathrm{A}_{\mathrm{it}-1}}\right)-0,071\left(\frac{\mathrm{PPEt}}{\mathrm{A}_{\mathrm{it}-1}}\right)
$$

Setelah mendapatkan nilai non- discretionary accruals dapat dihitung discretionary accruals, maka nilai dengan persamaan sebagai berikut:

$$
\mathrm{DAC}_{\mathrm{t}}=\frac{\mathrm{TAC}_{\mathrm{t}}}{\mathrm{A}_{\mathrm{it}-1}}-\mathrm{NDA}_{\mathrm{it}}
$$

\section{Statistik Deskriptif}

Tabel 2 menggambarkan statistik deskriptif untuk masing-masing variabel yang digunakan dalam penelitian ini. Dalam statistik deskriptif dijelaskan nilai minimum, maksimum, rata-rata (mean), dan standard deviation dari masingmasing variabel penelitian.

Tabel 2. Hasil Uji Statistik Deskriptif

Descriptive Statistics

\begin{tabular}{|l|r|r|r|r|r|}
\hline & \multicolumn{1}{|c|}{$\mathrm{N}$} & Minimum & Maximum & \multicolumn{1}{c|}{ Mean } & Std. Deviation \\
\hline DAC & 309 & -.5151171374 & .4758221550 & .0364925043 & .1048371425 \\
PROF & 309 & -.2396864954 & .4452621327 & .0560885711 & .0999528885 \\
INDP & 309 & 1.0 & 6.0 & 2.861 & 1.7104 \\
SIZE & 309 & 10.99807789 & 14.38993649 & 12.22519422 & .6721937153 \\
LEV & 309 & .0504582888 & 3.029085698 & .5197611496 & .3872481813 \\
Valid N (listwise) & 309 & & & & \\
\hline
\end{tabular}


Keterangan:

DAC : Discretionary accruals atau manajemen laba

PROF : Profitabilitas

INDP : Independensi auditor

SIZE : Ukuran perusahaan

LEV : Leverage

Hasil pengujian statistik frekuensi untuk variabel kualitas audit ditunjukkan pada tabel berikut:

Tabel 3. Hasil Uji Statistik Frekuensi (Kualitas Audit)

\begin{tabular}{|c|c|c|c|c|c|}
\hline \multicolumn{6}{|c|}{ KA } \\
\hline & & Frequency & Percent & Valid Percent & $\begin{array}{c}\text { Cumulative } \\
\text { Percent }\end{array}$ \\
\hline \multirow[t]{3}{*}{ Valid } & .0 & 201 & 65.0 & 65.0 & 65.0 \\
\hline & 1.0 & 108 & 35.0 & 35.0 & 100.0 \\
\hline & Total & 309 & 100.0 & 100.0 & \\
\hline
\end{tabular}

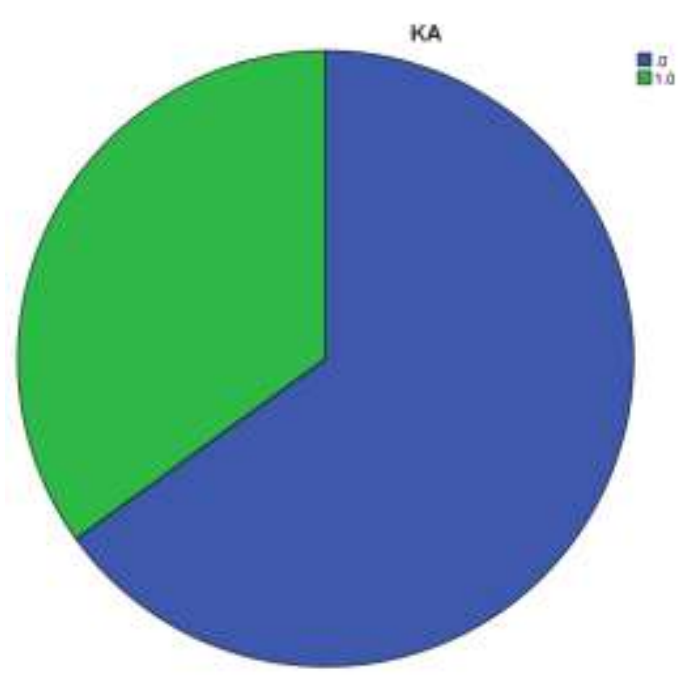

Gambar 2. Diagram Pie untuk Frekuensi Kualitas Audit

\subsection{Uji Normalitas}

Pengujian normalitas dilakukan dengan menggunakan KolmogorovSmirnov Test. Jika nilai asymp sig (2tailed) di atas 0,05 maka data residual terdistribusi normal. Hasil uji normalitas dengan menggunakan uji Kolmogorov-smirnov ditunjukkan pada tabel berikut: 
Pengaruh Profitabilitas, Kualitas Audit, Independensi Auditor, Ukuran Perusahaan, dan Leverage Terhadap Manajemen Laba (Studi Empiris Pada Perusahaan Manufaktur Yang Terdaftar Di Bursa Efek Indonesia

Tahun 2013-2015)

Tabel 4. Hasil Uji Kolmogorov-Smirnov

One-Sample Kolmogorov-Smirnov Test

\begin{tabular}{|ll|r|}
\hline & & $\begin{array}{r}\text { Unstandardiz } \\
\text { ed Residual }\end{array}$ \\
\hline $\mathrm{N}$ & 309 \\
Normal Parameters ${ }^{\mathrm{a}, \mathrm{b}}$ & Mean & .0000000 \\
Most Extreme Differences & Std. Deviation & .10150255 \\
& Absolute & .101 \\
Kolmogorov-Smirnov Z & Positive & .101 \\
Asymp. Sig. (2-tailed) & Negative & -.073 \\
& & 1.779 \\
\end{tabular}

a. Test distribution is Normal.

b. Calculated from data.

Nilai asymp sig (2-tailed) yang dilakukan uji outlier dengan dihasilkan adalah 0,004 atau di standarisasi z-score. Hasil uji bawah 0,05, sehingga dapat Kolmogorov-smirnov setelah uji disimpulkan data residual tidak outlier dutunjukkan pada tabel terdistribusi normal. Untuk berikut:

mengatasi masalah normalitas

Tabel 5. Hasil Uji Kolmogorov-Smirnov setelah Uji Outlier

One-Sample Kolmogorov-Smirnov Test

\begin{tabular}{|ll|r|}
\hline & & $\begin{array}{r}\text { Unstandardiz } \\
\text { ed Residual }\end{array}$ \\
\hline $\mathrm{N}$ & 309 \\
Normal Parameters & Meb & .0000000 \\
Most Extreme Differences & Std. Deviation & .07982232 \\
& Absolute & .073 \\
Kolmogorov-Smirnov Z & Positive & .073 \\
Asymp. Sig. (2-tailed) & & -.046 \\
\end{tabular}

a. Test distribution is Normal.

b. Calculated from data.

Setelah dilakukan uji outlier, nilai signifikansi yang diperoleh sebesar 0,072 yaitu lebih besar dari 0,05 , sehingga dapat disimpulkan bahwa variabel yang diuji telah terdistribusi normal. 
4.3 Uji Asumsi Klasik

\subsubsection{Uji Multikolonieritas}

Uji multikolonieritas bertujuan unuk menguji apakah dalam model regresi ditemukan adanya korelasi antar variabel independen (Ghozali, 2013). Hasil dari uji multikolonieritas ditunjukkan pada tabel berikut:

Tabel 6. Hasil Uji Multikolonieritas

Coefficients $^{\mathrm{a}}$

\begin{tabular}{|ll|r|r|}
\hline \multirow{2}{*}{ Model } & \multicolumn{2}{|c|}{ Collinearity Statistics } \\
\cline { 3 - 4 } & & Tolerance & \multicolumn{1}{l|}{ VIF } \\
\hline 1 & PROF & .690 & 1.449 \\
& KA & .895 & 1.118 \\
& INDP & .992 & 1.008 \\
& SIZE & .977 & 1.024 \\
& LEV & .742 & 1.347 \\
\hline
\end{tabular}

a. Dependent Variable: DAC

Berdasarkan hasil uji

multikolonieritas pada Tabel 6, dapat disimpulkan bahwa tidak terjadi multikolonieritas pada model regresi. Hal ini dapat dilihat dari nilai Tolerance semua variabel independen memiliki nilai yang lebih besar dari 0,10 dan nilai VIF kurang dari 10.

\subsubsection{Uji Autokorelasi}

Uji autokorelasi bertujuan untuk menguji apakah dalam model regresi linear ada korelasi antara kesalahan pengganggu pada periode $\mathrm{t}$ dengan kesalahan pengganggu pada periode t-1 (sebelumnya) (Ghozali, 2013). Autokorelasi dalam penelitian ini diuji dengan menggunakan Runs Test. Hasil uji autokorelasi ditunjukkan pada tabel berikut:

Tabel 7. Hasil Uji Autokorelasi

Runs Test

\begin{tabular}{|l|r|}
\hline & $\begin{array}{c}\text { Unstandardiz } \\
\text { ed Residual }\end{array}$ \\
\hline Test Value $^{\text {a }}$ & -.00203 \\
Cases $<$ Test Value & 154 \\
Cases >= Test Value & 155 \\
Total Cases & 309 \\
Number of Runs & 152 \\
Z & -.399 \\
Asymp. Sig. (2-tailed) & .690 \\
\hline
\end{tabular}

a. Median 
Pengaruh Profitabilitas, Kualitas Audit, Independensi Auditor, Ukuran Perusahaan, dan Leverage Terhadap Manajemen Laba

(Studi Empiris Pada Perusahaan Manufaktur Yang Terdaftar Di Bursa Efek Indonesia

Tahun 2013-2015)

Berdasarkan hasil pengujian regresi terjadi ketidaksamaan autokorelasi pada Tabel 7 , dapat variance dari residual satu dilihat nilai Asymp. Sig. sebesar pengamatan ke pengamatan lain 0,690 atau lebih besar daripada 0,05, (Ghozali, 2013). Dalam penelitian sehingga dapat disimpulkan bahwa ini, heteroskedastisitas diuji dengan tidak terjadi autokorelasi antar nilai melihat ada tidaknya pola tertentu residual. pada grafik scatterplot antara SRESID dan ZPRED. Hasil uji

\subsubsection{Uji Heteroskedastisitas}

Uji heteroskedastisitas bertujuan untuk menguji apakah dalam model heteroskedastisitas ditunjukkan pada grafik berikut:

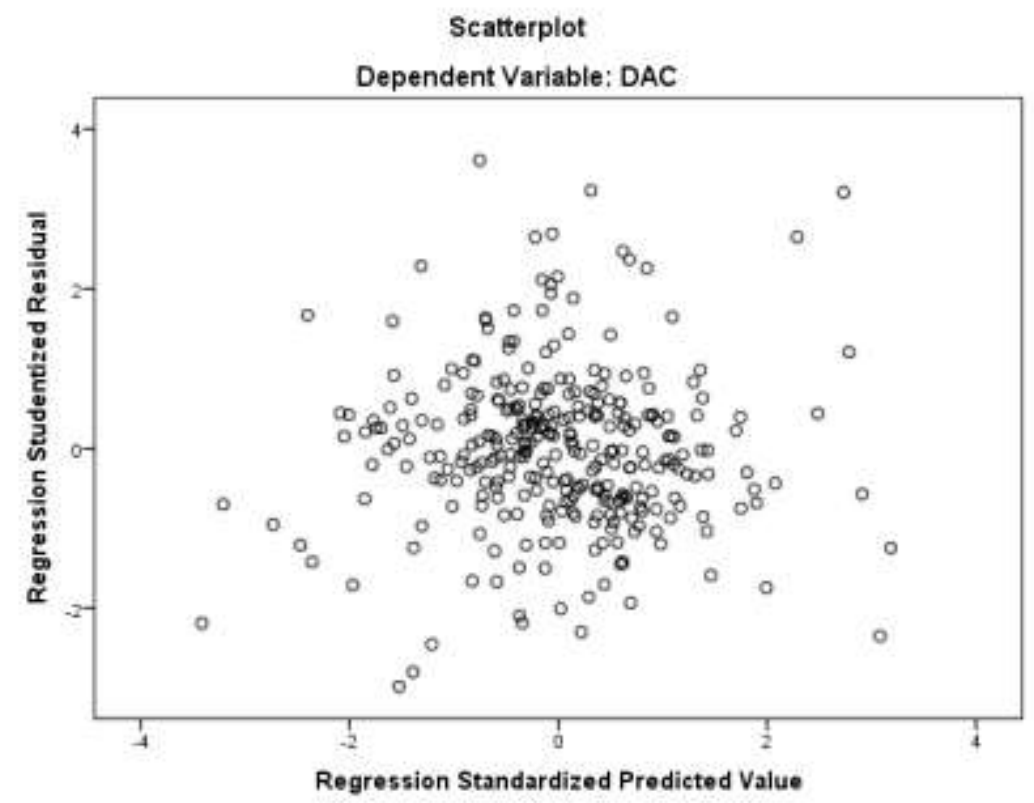

Gambar 3. Hasil Uji Heteroskedastisitas

Berdasarkan hasil pengujian heteroskedastisitas pada Gambar 3, dapat dilihat bahwa tidak terdapat pola tertentu pada grafik scatterplots. Titik-titik pada grafik scatterplots tidak membentuk pola tertentu dan tersebar baik di atas maupun di

bawah angka 0 pada sumbu $y$, sehingga dapat disimpulkan bahwa tidak terjadi heteroskedastisitas pada penelitian ini.

\subsection{Uji Hipotesis}




\subsubsection{Uji Koefisien Determinasi (adjusted $\mathbf{R}^{2}$ )}

Tabel 8. Hasil Uji Koefisien Determinasi (adjusted $\mathbf{R}^{2}$ )

Model Summary ${ }^{\mathrm{b}}$

\begin{tabular}{|l|l|r|r|c|}
\hline Model & R & R Square & $\begin{array}{c}\text { Adjusted R } \\
\text { Square }\end{array}$ & $\begin{array}{c}\text { Std. Error of } \\
\text { the Estimate }\end{array}$ \\
\hline 1 & $.245^{\mathrm{a}}$ & .060 & .044 & .0804782233 \\
\hline
\end{tabular}

a. Predictors: (Constant), LEV, INDP, SIZE, KA, PROF

b. Dependent Variable: DAC

Berdasarkan Tabel 8, nilai R sebesar 0,245 menunjukkan bahwa profitabilitas, kualitas audit, independensi auditor, ukuran perusahaan, dan leverage memiliki korelasi rendah karena berkisar antara 0,20 - 0,399. Nilai $\mathrm{R}$ square dalam penelitian ini adalah sebesar 0,060. Nilai adjusted $\mathrm{R}^{2}$ yang diperoleh adalah 0,044 yang berarti seluruh variabel independen dalam penelitian ini hanya mampu menjelaskan variasi dari variabel dependen sebesar $4,4 \%$, sedangkan sisanya sebesar $95,6 \%$ dijelaskan oleh faktor-faktor lain yang tidak termasuk dalam model penelitian ini. Standard Error of Estimate (SEE) yaitu sebesar 0,0804782233.

\subsubsection{Uji Signifikansi Simultan (Uji Statistik F)}

Tabel 9. Hasil Uji Signifikansi Simultan (Uji Statistik F)

ANOVA $^{\mathrm{a}}$

\begin{tabular}{|ll|r|r|r|r|r|}
\hline \multicolumn{2}{|c|}{} & \multicolumn{1}{c|}{$\begin{array}{c}\text { Sum of } \\
\text { Squares }\end{array}$} & $\mathrm{df}$ & Mean Square & $\mathrm{F}$ & Sig. \\
\hline 1 & Regression & .125 & 5 & .025 & 3.855 & $.002^{\mathrm{b}}$ \\
& Residual & 1.962 & 303 & .006 & & \\
& Total & 2.087 & 308 & & & \\
\hline
\end{tabular}

a. Dependent Variable: DAC

b. Predictors: (Constant), LEV, INDP, SIZE, KA, PROF

Berdasarkan Tabel 9, nilai $F$ yang diperoleh dari hasil uji di atas adalah 3,855 dengan nilai signifikansi sebesar 0,002. Nilai signifikansi tersebut lebih kecil daripada 0,05 sehingga dapat disimpulkan bahwa profitabilitas, kualitas audit, independensi auditor, ukuran perusahaan, dan leverage secara simultan berpengaruh terhadap manajemen laba. 
(Studi Empiris Pada Perusahaan Manufaktur Yang Terdaftar Di Bursa Efek Indonesia

4.4.3 Uji Signifikansi Parameter Individual (Uji Statistik t)

Tabel 10. Uji Signifikansi Parameter Individual (Uji Statistik t)

Coefficients $^{a}$

\begin{tabular}{|c|c|c|c|c|c|c|}
\hline \multirow[b]{2}{*}{ Mod } & & \multicolumn{2}{|c|}{ Unstandardized Coefficients } & \multirow{2}{*}{$\begin{array}{c}\begin{array}{c}\text { Standardized } \\
\text { Coefficients }\end{array} \\
\text { Beta }\end{array}$} & \multirow[b]{2}{*}{$t$} & \multirow[b]{2}{*}{ Sig. } \\
\hline & & $B$ & Std. Error & & & \\
\hline \multirow[t]{6}{*}{1} & (Constant) & -.012 & .043 & & -.291 & .772 \\
\hline & PROF & .278 & .065 & .289 & 4.303 & .000 \\
\hline & $K A$ & -.013 & .010 & -.074 & -1.259 & .209 \\
\hline & INDP & .001 & .003 & .017 & .303 & .762 \\
\hline & SIZE & .002 & .003 & .025 & .448 & .655 \\
\hline & LEV & .036 & .022 & .105 & 1.623 & .106 \\
\hline
\end{tabular}

a. Dependent Variable: DAC

\section{DAC = -0,012 + 0,278 PROF - 0,013 KA + 0,001 INDP + 0,002 SIZE + 0,036 LEV}

Berdasarkan Tabel 10, diperoleh koefisien regresi sebesar 0,278 untuk variabel profitabilitas (PROF) yang diproksikan dengan Return on Assets (ROA). Variabel profitabilitas (PROF) memiliki nilai $\mathrm{t}$ sebesar 4,303 dengan tingkat signifikansi 0,000 atau lebih kecil dari 0,05. Hal ini menunjukkan bahwa $\mathrm{Ha}_{1}$ diterima, sehingga dapat disimpulkan profitabilitas yang diproksikan dengan Return on Assets (ROA) berpengaruh secara signifikan terhadap manajemen laba.

Berdasarkan Tabel 10, diperoleh koefisien regresi sebesar $-0,013$ untuk variabel kualitas audit (KA) yang diproksikan dengan ukuran
KAP. Variabel kualitas audit (KA) memiliki nilai $t$ sebesar $-1,259$ dengan tingkat signifikansi 0,209 atau lebih besar dari 0,05. Hal ini menunjukkan bahwa $\mathrm{Ha}_{2}$ ditolak, sehingga dapat disimpulkan kualitas audit yang diproksikan dengan ukuran KAP tidak berpengaruh secara signifikan terhadap manajemen laba. Hal ini didukung oleh statistik deskriptif ditunjukkan bahwa $65 \%$ perusahaan yang digunakan sebagai sampel diaudit oleh KAP Non-Big Four. Contohnya terdapat pada laporan keuangan PT Keramika Indonesia Assosiasi (KIAS) tahun 2013 yang diaudit oleh KAP Mulyamin Sensi Suryanto \& 
Lianny (KAP Non-Big Four) ditunjukkan bahwa nilai DAC yang diperoleh sebesar 0,007880768 atau mendekati 0 . Nilai DAC tersebut mengindikasikan minimnya kemungkinan perusahaan melakukan manajemen laba. Oleh karena itu, dapat disimpulkan kualitas audit tidak berpengaruh signifikan terhadap manajemen laba.

Berdasarkan Tabel 10, diperoleh koefisien regresi sebesar 0,001 untuk independensi auditor (INDP) yang diproksikan dengan audit tenure. Variabel independensi auditor (INDP) memiliki nilai $\mathrm{t}$ sebesar 0,303 dengan tingkat signifikansi 0,762 atau lebih besar dari 0,05. Hal ini menunjukkan bahwa $\mathrm{Ha}_{3}$ ditolak, sehingga dapat disimpulkan independensi auditor yang diproksikan dengan audit tenure tidak berpengaruh signifikan terhadap manajemen laba. Hal ini dikarenakan dalam pelaksanaan audit terdapat Standar Audit yang harus dipenuhi oleh auditor, yakni dinyatakan bahwa dalam semua hal yang berhubungan dengan perikatan, independensi dalam sikap mental harus dipertahankan oleh auditor. Sebagai contoh yaitu data laporan keuangan Asahimas Flat Glass Tbk tahun 2013 yang memiliki audit tenure sebesar 5, tetapi memiliki nilai DAC sebesar 0,002766899 atau mendekati 0. Nilai DAC tersebut mengindikasikan minimnya kemungkinan perusahaan melakukan manajemen laba. Hal ini menunjukkan lamanya perikatan audit antara auditor dengan klien tidak membatasi perilaku manajemen untuk melakukan manajemen laba.

Berdasarkan Tabel 10, diperoleh koefisien regresi sebesar 0,002 untuk variabel ukuran perusahaan (SIZE) yang diproksikan dengan logaritma total aset. Variabel ukuran perusahaan (SIZE) memiliki nilai $\mathrm{t}$ sebesar 0,448 dengan tingkat signifikansi 0,655 atau lebih besar dari 0,05. Hal ini menunjukkan bahwa $\mathrm{Ha}_{4}$ ditolak, sehingga dapat disimpulkan ukuran perusahaan yang diproksikan dengan logaritma total aset tidak berpengaruh signifikan terhadap manajemen laba. Hasil penelitian ini menunjukkan arah positif yang berarti semakin besar perusahaan, maka indikasi manajemen laba semakin tinggi. Hal ini dapat disebabkan karena rata-rata perusahaan yang dijadikan sampel 
(Studi Empiris Pada Perusahaan Manufaktur Yang Terdaftar Di Bursa Efek Indonesia

Tahun 2013-2015)

merupakan perusahaan besar yang memiliki total aset di atas 100 miliar rupiah. Di beberapa perusahaan, jumlah aset yang besar disebabkan oleh nilai yang besar pada beberapa akun, seperti akun persediaan, piutang berelasi, dan tanaman belum menghasilkan. Penentuan nilai akun tersebut menggunakan judgment manajemen, sehingga terdapat kemungkinan perusahaan melakukan manajemen laba. Selain itu, perusahaan besar juga perlu mempertahankan reputasinya agar terlihat baik di mata publik, dimana kondisi tersebut dapat mendorong perusahaan untuk memanipulasi laporan keuangan. Hasil penelitian ini juga menyatakan bahwa ukuran perusahaan tidak berpengaruh signifikan terhadap manajemen laba dikarenakan ukuran perusahaan yang diproksikan dengan logaritma total aset tidak menjadi tolak ukur dilakukannya manajemen laba pada perusahaan manufaktur. Hal ini dapat dibuktikan dari data laporan keuangan Asahimas Flat Glass Tbk tahun 2013 yang memiliki logaritma total aset sebesar 12,55165539, ditunjukkan nilai DAC yang diperoleh sebesar 0,002766899 atau mendekati 0. Nilai DAC tersebut mengindikasikan minimnya kemungkinan perusahaan melakukan manajemen laba. Oleh karena itu, ukuran perusahaan tidak berpengaruh signifikan terhadap manajemen laba. Berdasarkan Tabel 10, diperoleh koefisien regresi sebesar 0,036 untuk variabel leverage (LEV) yang diproksikan dengan debt to total assets. Variabel leverage (LEV) memiliki nilai t sebesar 1,623 dengan tingkat signifikansi 0,106 atau lebih besar dari 0,05. Hal ini berarti bahwa $\mathrm{Ha}_{5}$ ditolak, sehingga dapat disimpulkan leverage yang diproksikan dengan debt to total asset tidak berpengaruh signifikan terhadap manajemen laba. Hasil penelitian ini didukung oleh penelitian Pambudi dan Sumantri (2014), Jao dan Pagalung (2011), serta Noviana dan Yuyetta (2011) yang menyatakan bahwa leverage tidak berpengaruh signifikan terhadap manajemen laba. Menurut Jao dan Pagalung (2011), perusahaan dengan tingkat leverage yang tinggi akan menghadapi risiko default yang tinggi yaitu perusahaan terancam tidak mampu memenuhi kewajibannya. Sedangkan tindakan 
manajemen laba tidak dapat dijadikan mekanisme untuk menghindari pemenuhan kewajiban tersebut. Dari data laporan keuangan Saranacentral Bajatama Tbk (BAJA) tahun 2015, ditunjukkan bahwa rasio leverage yang dimiliki perusahaan adalah 0,829629427 atau sebesar $82,96 \%$, tetapi nilai DAC yang diperoleh adalah 0,004768118 atau mendekati 0 . Hal tersebut menunjukkan bahwa indikasi perusahaan melakukan manajemen laba sangat minim. Oleh karena itu, leverage tidak berpengaruh signifikan terhadap manajemen laba.

\section{SIMPULAN DAN SARAN}

\subsection{Simpulan}

Simpulan dari penelitian yang dilakukan adalah sebagai berikut:

1. $\mathrm{Ha}_{1}$ diterima yang berarti profitabilitas yang diproksikan dengan return on assets (ROA) berpengaruh signifikan terhadap manajemen laba.

2. $\mathrm{Ha}_{2}$ ditolak yang berarti kualitas audit yang diproksikan dengan ukuran KAP tidak berpengaruh signifikan terhadap manajemen laba.
3. $\mathrm{Ha}_{3}$ ditolak yang berarti independensi auditor yang diproksikan dengan audit tenure tidak berpengaruh signifikan terhadap manajemen laba.

4. $\mathrm{Ha}_{4}$ ditolak yang berarti ukuran perusahaan yang diproksikan dengan logaritma total aset tidak berpengaruh signifikan terhadap manajemen laba.

5. $\mathrm{Ha}_{5}$ ditolak yang berarti leverage yang diproksikan dengan debt to total asset tidak berpengaruh signifikan terhadap manajemen laba.

6. Uji simultan sebesar 0,002 menunjukkan bahwa profitabilitas, kualitas audit, independensi auditor, ukuran perusahaan, dan leverage secara simulltan berpengaruh terhadap manajemen laba.

\subsection{Keterbatasan}

Keterbatasan dalam penelitian ini adalah sebagai berikut:

1. Nilai adjusted $\mathrm{R}^{2}$ sebesar 0,044 yang berarti seluruh variabel independen dalam penelitian ini yang terdiri dari profitabilitas, kualitas audit, independensi auditor, ukuran perusahaan, dan 
Pengaruh Profitabilitas, Kualitas Audit, Independensi Auditor, Ukuran Perusahaan, dan Leverage Terhadap Manajemen Laba (Studi Empiris Pada Perusahaan Manufaktur Yang Terdaftar Di Bursa Efek Indonesia

Tahun 2013-2015)

leverage hanya mampu

menjelaskan variasi dari variabel

dependen sebesar $4,4 \%$ sedangkan

sisanya sebesar $95,6 \%$ dijelaskan

oleh faktor-faktor lain yang tidak

termasuk dalam model penelitian ini.

2. Periode yang diteliti dalam penelitian ini terbatas hanya 3 tahun yaitu tahun 2013-2015.

\subsection{Saran}

Saran yang dapat diberikan terkait dengan penelitian ini adalah sebagai berikut:

1. Peneliti selanjutnya dapat menambah variabel independen lain seperti kepemilikan manajerial, kepemilikan institusional, ukuran dewan komisaris, komite audit, dan auditor spesialis industri.

2. Penelitian selanjutnya dapat menambah jumlah periode penelitian menjadi lebih dari tiga tahun, sehingga sampel yang digunakan lebih dapat mewakili populasi.

\section{DAFTAR PUSTAKA}

Agustia, Dian. 2013. "Pengaruh Faktor Good Corporate Governance, Free Cash Flow, dan Leverage terhadap Manajemen Laba". Jurnal Akuntansi dan Keuangan. (Vol. 15; No. 1; 27-42).

Amertha, Indra Satya Prasavita. 2013. "Pengaruh Return on Asset pada Praktik Manajemen Laba dengan Moderasi Corporate Governance". E-Jurnal Akuntansi Udayana 4.2.

Amijaya, Muhammad Dody dan Andri Prastiwi. 2013. "Pengaruh Kualitas Audit terhadap Manajemen Laba". Diponegoro Journal of Accounting. (Vol. 2; No. 3; 1 13).

Arens, Alvin A., Randal J. Elder and Mark S. Beasley. 2014. Auditing and Assurance Services: An Integrated Approach. Fifteenth Edition. Pearson Education.

Atarwaman, Rita J. D. 2011. "Analisis Pengaruh Ukuran Perusahaan, Profitabilitas, dan Kepemilikan Manajerial terhadap Praktik Perataan Laba yang Dilakukan oleh Perusahaan Manufaktur pada Bursa Efek Indonesia (BEI)". Jurnal Ilmu Ekonomi ADVANTAGE. (Vol. 2; No. 2; 67-79). 
BAPEPAM. 1997. Surat Keputusan Ketua Bapepam Nomor Kep11/PM/1997 Tanggal 30 April 1997 tentang Perubahan Peraturan Nomor IX.C.7 tentang Pedoman Mengenai Bentuk Pernyataan Pendaftaran dalam Rangka Penawaran Umum oleh Perusahaan Menengah atau Kecil. Jakarta: Badan Pengawas Pasar Modal.

BAPEPAM. 2011. Surat Keputusan Ketua Bapepam Nomor Kep86/BL/2011 Tanggal 28 Februari 2011 tentang Independensi Akuntan yang Memberikan Jasa di Pasar Modal. Jakarta: Badan Pengawas Pasar Modal.

BAPEPAM. 2011. Surat Keputusan Ketua Bapepam Nomor Kep346/BL/2011 Tanggal 5 Juli 2011 tentang Penyampaian Laporan Keuangan Berkala Emiten atau Perusahaan Publik. Jakarta: Badan Pengawas Pasar Modal.

Christiani, Ingrid dan Yeterina Widi Nugrahanti. 2014. "Pengaruh Kualitas Audit terhadap Manajemen Laba". Jurnal Akuntansi dan Keuangan. (Vol. 16; No. 1; 52-62).

Dahlan, Ahmad, Gagaring Pagalung dan Tawakkal. 2013. "FaktorFaktor yang Mempengaruhi Independensi Auditor". Jurnal.
Erawan, I Gede Pandita dan I Gusti Ketut Agung Ulupui. 2013. "Manajemen Laba Sebelum dan Sesudah Pergantian Chief Executive Officer (CEO)". Ejurnal Akuntansi Udayana 3.1.

Financial Accounting Standards Board. 2008. Statement of Financial Accounting Concept. Norwalk: Financial Accounting Standards Board.

Gerayli, Mahdi Safari, Abolfazl Momeni Yanesari dan Ali Reza Ma'atoofi. 2011. "Impact of Audit Quality on Earnings Management: Evidence from Iran". International Research Journal of Finance and Economics. (Issue 66-2011).

Ghozali, Imam. 2013. Aplikasi Analisis Multivariate dengan Program IBM SPSS 21. Edisi Tujuh. Semarang: Badan Penerbit Universitas Diponegoro.

Godfrey, Jayne et al. 2014. Accounting Theory. Seventh Edition. Wiley.

Guna, Welvin I dan Arleen Herawaty. 2010. "Pengaruh Mekanisme Good Corporate Governance, Independensi Auditor, Kualitas Audit, dan Faktor Lainnya terhadap Manajemen Laba". Jurnal Bisnis dan Akuntansi. (Vol. 12; 53-68). 
Ikatan Akuntan Indonesia. 2014. Standar Akuntansi Keuangan Per 1 Januari 2015. Jakarta: Ikatan Akuntan Indonesia.

Institut Akuntan Publik Indonesia. 2011. Pernyataan Standar Auditing (PSA) No. 04. Jakarta: Institut Akuntan Publik Indonesia.

Jao, Robert dan Gagaring Pagalung. 2011. "Corporate Governance, Ukuran Perusahaan, dan Leverage terhadap Manajemen Laba Perusahaan Manufaktur Indonesia". Jurnal Akuntansi \& Auditing. (Vol. 8; No.1; November 2011).

Kusumaningtyas, Metta. 2012. "Pengaruh Independensi Komite Audit dan Kepemilikan Institusional terhadap Manajemen Laba". Jurnal Prestasi. (Vol. 9; No. 1; Juni 2012).

Kusumawardhani, Indra. 2012. "Pengaruh Corporate Governance, Struktur Kepemilikan, dan Ukuran Perusahaan terhadap Manajemen Laba". Jurnal Akuntansi dan Sistem Teknologi Informasi. (Vol. 9; 41-54).

Limanto, Danny dan Zaenal Fanani. 2014. "Do IFRS Adoption, Firm Size, and Firm Leverage Influence Earnings Management? Evidence from Manufacturing Firm listed in Indonesia Stock Exchange". Simposium Nasional Akuntansi XVII.
Lind, Douglas A., William G. Marchal, and Samuel A. Wathen. 2010. Statistical Technique in Business and Economics. Fourteenth Edition. McGraw Hill.

Noviana, Sindi Retno dan Etna Nur Afri Yuyetta. 2011. "Analisis Faktor-Faktor yang Mempengaruhi Praktik Perataan Laba". Jurnal Akuntansi \& Auditing. (Vol. 8; No. 1; 69-82).

Pambudi, Januar Eky dan Farid Addy Sumantri. 2014. "Kualitas Audit, Ukuran Perusahaan, dan Leverage terhadap Manajemen Laba". Simposium Nasional Akuntansi XVII.

Peraturan Pemerintah Republik Indonesia. 2015. Peraturan Pemerintah Republik Indonesia Nomor 20 Tahun 2015 tentang Praktik Akuntan Publik, Indonesia.

Purwanti, Rahayu Budhi. 2012. "Pengaruh Kecakapan Manjerial, Kualitas Auditor, Komite Audit, Firm Size, dan Leverage terhadap Earnings Management". Skripsi. Semarang: Program Sarjana Fakultas Ekonomika dan Bisnis Universitas Diponegoro.

Saksakotoma, Paramitha Hana dan Nur Cahyonowati. 2014. "Determinan Integritas Laporan Keuangan Perusahaan Manufaktur di Indonesia". Jurnal. (Vol. 3; No 2; 2014). 
Scott, William R. 2012. Financial Accounting Theory. Sixth Edition. Canada: Pearson Prentice Hall.

Sekaran, Uma dan Roger Bougie. 2013. Research Methods for Business. Sixth Edition. Wiley.

Subramanyam, K. R. 2014. Financial Statement Analysis. Eleventh Edition. McGrawHill Education.

Sugiyono. 2010. Statistika untuk Penelitian. Bandung: Alfabeta.

Sulistyanto, Sri. 2008. Manajemen Laba Teori dan Model Empiris. Grasindo.

Susiana dan Arleen Herawaty. 2007. "Pengaruh Independensi, Mekanisme Corporate Governance, dan Kualitas Audit terhadap Integritas Laporan Keuangan”. Simposium Nasional Akuntansi X.
Tjun Tjun, Lauw, Elyzabet Indrawati Marpaung dan Santy Setiawan. 2012. "Pengaruh Kompetensi dan Independensi Auditor terhadap Kualitas Audit". Jurnal Akuntansi. (Vol. 4; No. 1 ; 33-56).

Wiryadi, Arri dan Nurzi Sebrina. 2013. "Pengaruh Asimetri Informasi, Kualitas Audit, dan Struktur Kepemilikan terhadap Manajemen Laba". WRA. (Vol. 1; No. 2; Oktober 2013).

Wiyadi, Rina Trisnawati, Noviana Puspitasari, dan Noer Sasongko. 2016. "Pengaruh Asimetri Informasi, Leverage, dan Profitabilitas terhadap Manajemen Laba Riil pada Perusahaan Manufaktur di Indonesia". The $3^{\text {rd }}$ University Research Colloquium 2016. ISSN 24079189.

Yulia, Mona. 2013. "Pengaruh Ukuran Perusahaan, Profitabilitas, Financial Leverage, dan Nilai Saham terhadap Perataan Laba (Income Smoothing) pada Perusahaan Manufaktur, Keuangan, dan Pertambangan yang Terdaftar di BEI". Skripsi. Padang: Fakultas Ekonomi Universitas Negeri Padang. 